\title{
遺伝子診断・ゲノム編集技術の倫理的課題
}

岩本禎彦*

\section{Ethical problems in gene testing and genome editing}

Sadahiko IwAMOTO

要約：最近の遺伝子解析技術の爆発的進化は, 臨床医学に扔ける遺伝子診断 を，ますます身近なものにすると期待されている，遺伝子診断の中でも生殖 細胞系列の遺伝子診断は, (1)将来の発症予見性, (2)生涯変化しないこと, (3) 非発症保因者を診断できること, (4)血縁者, 人種, 地域共同体に共有されて いる可能性があること, という, 他の医療情報にはない特徵を持つために, 最も倫理的な配慮が必要である, とりわけ保因者診断, 発症前診断, 出生前 診断には，遺伝カウンセリングが必須である，また，次世代シークエンサー を用いて全ゲノムやエクソーム解析を行った場合には，本当に診断したかっ た症候に関連した遺伝子異常だけではなく，予期せ女遺伝子に配列異常が見 出された場合にどう伝えるべきかが問題になっている，遺伝性疾患の根本的 治療として, 従来, ウイルスベクターを用いた治療が行われているが, 受精 卵や胚を治療の対象とすることは禁じられている。最近, 中国で受精卵のゲ ノム編集が実施されたことが発表され，物議を釀している，ヒトの生殖細胞 のゲノム編集についての議論を，日本でも開始するべきと考える，その際， 人類遺伝学を正しく理解しておくことが重要なことである.

Key words: genetic diagnosis, gene therapy, genetic variation, prenatal diagnosis, mutation frequency

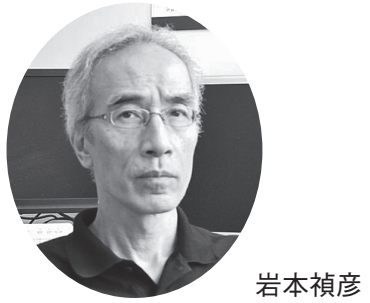

1982年3月 自治医科大学医学部 卒業

同年4月 鳥取県立中央病院にて 初期研修

1984年4月 鳥取県僻地中核病院 勤務 ( 1991年3月)

1991年4月 自治医科大学 法医 学 $\cdot$ 人類遺伝学 助教

1992年4月 同 講師

1996年2月 同 准教授

1997 年9月 University of Washington, visiting scientist 1998年7月 自治医科大学 復職 2004年4月 自治医科大学 人類 遺伝学部門 教授

2011年4月 現職

\section{1.はじめに}

血友病や遺伝性血小板凝集異常症のような単一遺 伝性疾患は，それぞれの疾患に関連する遺伝子産物 に何らかの機能的変化をもたらす塩基配列の異常が 原因となる。このことは, 1970 年頃からの分子生 物学の発展と共に明らかにされ，今日，周知のもの となってきた。遺伝性疾患が示す様々な表現型のバ リエーションについても，また，薬荗代謝や副作用 に関連する遺伝的多型など医療行為の選択に関して

\footnotetext{
*責任者連絡先 :

自治医科大学分子病態治療研究センター人類遺伝学研究 部

广 329-0498 栃木県下野市薬師寺 3311-1

Tel: 0285-58-7341, Fax: 0285-44-4902

E-mail: siwamoto@jichi.ac.jp
}

も，遺伝子診断はますます重要な情報となっていく だろう。さらに，最近の遺伝子解析技術の爆発的進 化は, ヒト全ゲノムの解読に要するコストを 20 年 前の 100 万分の 1 にまで下げることに成功した。こ のことによって, 臨床医学における遺伝子診断は, ますます身近なものになっていくだろうと期待され ており，このタイミングで，遺伝子診断とその治療 についてもう一度，考え直すことは重要なことであ る。遺伝子解析研究倫理に関わりつつ遺伝カウンセ リングにも携わっている経験をもとに，遺伝医療に おける倫理問題を論じてみたい.

\section{2. 遺伝子診断の倫理的課題}

1）生殖細胞系列遺伝子診断とは 遺伝子の本態，即ち DNA や RNA を用いた診断行 
為は, 遺伝性疾患 (生殖細胞系列：その個体が生来 保有する遺伝情報を原因とする疾患)だけが対象で はない. ガンや白血病のように体細胞のクローン性 増殖によって特徵的に現れるゲノムの構造異常や遺 伝子発現の変化を調べる体細胞遺伝子検査, そして 感染症の病原体の核酸を検出する病原体遺伝子検査 も遺伝子診断として臨床的に行われている。 これら の遺伝子診断の一部は既に, 保険収載され, 一般的 になってきているが, この中で, 最も倫理的問題を 孕み，その実施に慎重を期すべきなのは，生殖細胞 系列の遺伝子診断である。なぜなら，その遺伝情報 は全ての体細胞に共通して存在し，しかも，親や兄 弟，子供ともその情報を共有している可能性がある から，患者個人を対象とした医療行為として診断を 行っているにもかかわらず，家族に共通するかも知 れない情報を明らかにしようとしていることを意識 する必要があるからである。他の医療情報にはない 生殖細胞系列の遺伝情報が持つ特殊性は, (1)将来の 発症予見性, (2)生涯変化しないこと, (3)非発症保因 者を診断できること, (4)血縁者, 人種, 地域共同体 に共有されている可能性があること，にある。

\section{2）本邦特有の遺伝医療における問題}

遺伝は家族を巻き込んだ問題となり得ることであ るという論点から，ここで，遺伝性疾患の家族にお ける状況の日米比較を行った研究結果を, 紹介して おく，米国では，遺伝性疾患の子供が生まれても， 運が悪かったと思い, 誰のせいでもないと捉える. 日本では遺伝性疾患の子供が生まれたことで家系に “污れた血”が存在することに気づき，それを恥とし て隠す，そしてしばしばその血が入ってきた契機に なったと疑われる母親は家族から迫害の対象になる ことが, 報告されている1). この調査が行われてか ら四半世紀経とうとしているのに，それほど状況は 変わっていないことを遺伝カウンセリングのたびに 感じている。なぜだろうか。一つは，日本人におけ る遺伝学教育の不足がある。中高等教育におけるカ リキュラムの不足だけではなく，医学部においても 遺伝学講義が独立した科目として教育が行われてい る大学の方が少ないことは, 正しい遺伝医療を主体 的に実践，啓蒙すべき人材を育てる能力に欠けてい ることを示唆している，もう一つは，幸いにも日本 人には白人に高頻度 $(1 / 2 \sim 3000$ 人)に生まれる囊胞
性線維症やアフリカ系民族の鎌状赤血球症 $(1 / 50$ ～ 100 人)のような身近な遺伝病がなかったことが, か えって私たちに遺伝性疾患を対岸の火事として捉え させ，社会あるいは人類全体にとって不可避の多様 性の一部と認識させることを妨げてきたのだと考え られる。

\section{3）遺伝子解析研究と遺伝学的検査の違いとそれぞ れの倫理規範}

患者あるいはクライエント自身に対する臨床的判 断を目的とした遺伝子診断は, 遺伝学的検査の一部 に分類される。これに対し, 遺伝子解析によって, 診断可能かどうか検討したり, 新たな遺伝子解析技 術を開発することなどを目的としてヒトゲノムを扱 う場合は, 研究に分類される。遺伝子を扱う研究に 対する倫理的規範は, 文部科学省, 厚生労働省およ び経済産業省が共同で作成した「ヒトゲノム・遺伝 子解析研究に関する倫理指針」(平成 25 年 2 月 8 日 全部改正)としてまとめられており，様々な規制が設 けられている。これに対し, 遺伝子診断の倫理規範 としては, 日本人類遺伝学会と遺伝医学関連学会が 提唱し日本医学会がまとめた「遺伝学的検査のガイ ドライン」があるが, 様々な留意点が述べられてい るに過ぎず，規制ではない，しかし，一般臨床では 意識することのない遺伝医療における配慮すべき事 項が記載されているので, 主な留意点を次に紹介す るが，できればご一読いただきたい。

\section{4）遺伝学的検査における倫理的課題}

では, 遺伝学的検査が孕む, 倫理的課題にはどの ようなものがあるだろうか. まずは, 遺伝学的検査 とは何かを理解することから始めなければならない. 遺伝学的検査とは, 前述したような生殖細胞系列の 遺伝情報をDNA あるいは RNA を用いて調べる検 査(狭義の遺伝子検査)だけではない。遺伝性疾患の 診断に関わる医療行為は全て対象になると言って良 い. 例えば，先天代謝異常症の新生巟マススクリー ニングについても「遺伝学的検査のガイドライン」の 対象である。遺伝子情報と生化学情報等を同レベル で扱うことは, 従来, 趨勢であった「ゲノム特殊論 (genetic exceptionalism) 」) からすれば，奇異に映る であろう。しかし, 遺伝性疾患の診断そのものが遺 伝情報であることに気づけば, 遺伝学的検査の方法 がどうあれ，既に遺伝性疾患を発症している患者の 
検査結果ならびに診断名については，全て個人情報 として高度に秘匿されるべき事項であることは明ら かである，逆に医療者側にとってみれば，診断根拠 となった検查方法が遺伝子情報であろうと生化学情 報であろうと，診療方針に大きな影響を持つ検査結 果は，患者のケアに関わるスタッフ全員が共有すべ き情報として診療録に記載されるべきである。しか し，前述したように，遺伝子情報はその普遍性(全て の細胞に共有) と生物学的特性(疾患によっては高度 の予見性がある)故に, 次に述べるような状況では, 患者血縁者にも必要な情報となるということが，他 の遺伝学的検查と決定的に異なる。即ち, 生化学的 遺伝検査と異なり，血清や尿などの特定の試料を必 要とせず，身体のどの細胞から得られたかにかかわ らずゲノム DNAさえ手に入れば良いし，未発症で あっても，原因となる遺伝的バリエーションを保有 しているかどうかを明らかにできる。したがって， 場合によっては，その情報は親子何世代にもわたっ て必要とされる可能性があるため, 遺伝情報は, 通 常の診療録よりも長期間の保存が必要になる。

患者血縁者に遺伝学的検査が行われる状況として は, (1)非発症保因者の診断, (2)発症前診断, (3)出生 前診断がある，血友病患者の母親は非発症保因者の 可能性があるが，患者の遺伝子変異が既知の場合に は凝固因子レベルの検査よりも遺伝子検査の方が, クリアカットな保因者診断を可能にする。保因者か どうかを診断することは，次子における疾患の再発 リスクを知らせることになり，専門スタッフによる 遺伝カウンセリングとインフォームド・コンセント が必要なことは当然である。

神経変性疾患や遺伝性ガン症候群のように一定年 齢までは発症しない疾患についても遺伝子診断はそ の発症原因となる遺伝子異常を検出することが可能 である。未発症アットリスク (at risk)の人の検査を発 症前診断といい，遺伝性乳癌を例にとると，乳癌発 生母地を予彻除することによってリスクを低減で きるメリットがある。しかし，ハンチントン病のよ うに現在予防法も治療法もない疾患の場合, 病的ア リルを持たないと判明した場合ならまだしも，発症 前に原因遺伝子に異常があることを告知された場合， 絶望の淵に追い込まれるだけで，本人にとって全く 福音とはならない。したがって, 治療法のない疾患
の発症前診断は，慎重を期すべきであり，やはり，専 門スタッフによる遺伝カウンセリングが必須である.

出生前診断は，アットリスクの胎児あるいは肧が 原因遺伝子に異常を持つかどうかを，羊水の細胞や 受精卵の一部あるいは最近では母体血漿中を流れる 無細胞性の胎児 DNA のいずれかを用いて，明らか にしょうとする行為である。生まれ来る子供が五体 満足であることは全ての親の願いだ。しかし，出生 前診断の主たる目的は，胎児あるいは胚が出生後， 重篤な遺伝性疾患を発症することを回避することに ある。即ち，発症することが予見された場合は，胎 児であれば人工妊娠中絶し，胚であれば子宮に移植 しないことを判断するための診断技術とも言える. したがって, 出生前診断は「生命の質」に基づく選択 的出産によって優生学的な差別を助長する危険を内 包していると指摘するグループもある3 . 優生学の 思想は, ナチスの優生思想が有名で, 遺伝病, 遺伝 的精神疾患が減れば，社会保障費が減少し，産業の 生産性が上がり，軍隊も優秀になるという，民族改 善思想であった。この目的のために多くの虐殺行為 や，強制不妊手術が行われたことから，優生学はネ ガティブな響きを持つようになった。今日このよう な国家による優生学はさすがに廃れたが，個人によ る優生学が出現し, 出生前診断はまさにそのツール であると批判されるわけである。しかしながら，一 人目の子供が重篤な遺伝性疾患でそのケアに疲れ果 て, 次の子は健康で手のかからない子供でなければ 育てられないと思う親の気持ちは理解でき，そのた めに出生前診断を行うことは許されて良いような気 がする，日本人類遺伝学会は，出生前診断に関する 見解を発表しており，妊娠期前半に行われる出生前 診断は，胎児が重篤な遺伝性疾患などに罹患してい る可能性があり，何らかの手法により精度の高い診 断情報が得られる場合に，考慮されるものとしてい る (http://jshg.jp/introduction/notifications/19941200. html）。しかし，重篤な遺伝性疾患とそうでない疾 患との間に明確な線引きはないし，適応疾患名がリ ストアップされているわけでもない。一般に，重篤 な遺伝性疾患とは比較的若年発症し, 治療法はな く，死亡率も高い疾患を指し，この意味では，血友 病を出生前診断の適応とすることには無理がある. しかし，親が熱望する場合，生命倫理を盾にそれを 
明確に拒絶するのは，易しいことではない．

もう一つ, 遺伝子解析技術の進歩によって新たに 浮上した問題がある。次世代シークエンサーは全ゲ ノムやエクソーム配列を比較的簡単に解析可能とし たが，その結果，本当に診断したかった症候に関連 した遺伝子異常だけではなく, 予期せぬ遺伝子に配 列異常が見出されることがある (incidental findings). 例えば，遺伝性乳がん関連遺伝子 BRCA1に乳がん 発症リスクを高める既知の遺伝子異常が見いだされ た場合は，その結果は DNA 提供者に伝えられるべ きであろう。しかし，発症リスクとどう関係がある かわからない配列のバリエーションはどうだろう か.ノックインマウスを作製して, 発症リスクを高 める可能性があることを確かめる義務があるとは思 えないが，少なくとも調べた全配列情報の所得権は 法的には本人に帰属するとされているので，とりあ えず配列情報を返せばすむのだろうか。あるいは， 神経変性疾患のような発症前診断になってしまう場 合はどうすべきだろうか. 全ゲノムのリシークエン スを行うと， 30〜 40 個の遺伝子変異がみつかると の報告もある.アメリカ医療遺伝学・ゲノム学協会 は, 治療可能な 24 疾患に関連する 56 遺伝子につい ては結果を患者に返すべきだと勧告したが4)，日本 では，それをどう扱うべきかについて議論が始まっ たばかりである。

\section{3. ゲノム編集技術の倫理的課題}

\section{1）遺伝子治療技術の進歩}

遺伝性疾患をもたらす遺伝子異常が見出された場 合, 遺伝子の機能を回復させることによって, 根本 的な治癒を可能にしたいと, 患者を目の前にしたこ とのある医療者ならば誰しもが思うことだろう。遺 伝性疾患の遺伝子治療の試みは, 1990 年, 米国に おいてレトロウイルスベクターを用いた ADA 欠損 症に始まり ${ }^{5)}$, 既に, 3000 例以上の成功例がある. ADA 欠損症における遺伝子治療のプロトコルは, 免疫制御の中心を担うリンパ球の機能不全の結果と して生ずる免疫不全を, ADA酵素遺伝子発現カセッ トをゲノム DNA に挿入することによって安定的な 酵素の発現を促し, 疾患を改善しようとする戦略で ある。さらに根治的な方法として, 造血幹細胞にべ
クターを導入することによって, $\mathrm{X}$ 連鎖免疫不全症 の治療が行われ，遺伝病の最初の治癒ケースとして 報告された6)。しかし，その後のトライアルで危惧 していた事態が生じ，遺伝子治療戦略の見直しを迫 られた。レトロウイルスベクターは，逆転写された DNAが，ゲノムにランダムに挿入されるため，挿入 場所によっては, 周辺遺伝子の機能を破壊したり, 逆に発現㐫進を生ずる場合がある。患者造血幹細胞 の癌遺伝子近傍に投与されたべクターが，挿入され たことによって, 癌遺伝子を活性化し白血病を発症 したのだ゙.ここのことから得られた教訓は、レトロ ウイルスやレンチウイルスのようにゲノムにインテ グレートされるベクターを, 殊に多能性幹細胞に用 いる遺伝子治療後は腫瘍の発生に留意しなければな らないということだった。アアデノ随伴ウイルスベク ター (AAVベクター) は，めったにゲノムに挿入さ れることはなく, ベクターDNA はエピゾームに保 存され, 細胞分裂の少ない細胞では, 搭載された遺 伝子が安定的に発現する。AAVベクターを用いた 遺伝子治療は, 副腎白質ジストロフィーや血友病を 対象に実施され，一定の成果を挙げている ${ }^{8,9}$.

\section{2）遺伝子治療に関する倫理規範}

遺伝子治療の臨床研究に関する倫理指針は平成 14 年, 文部科学省と厚生労働省が公布し, 平成 20 年改正され, 現在に至っている。この指針では, 遺 伝子治療を臨床応用する遺伝性疾患の対象として, やはり, 重篤な遺伝性疾患としている。しかも, 遺 伝子治療による治療効果が, 現在可能な他の治療方 法に比べて明らかに優れていることが予想されるも のであって, 遺伝子治療を受けるものの利益が不利 益を上回ると予想されるものであることとされてい る。また，生殖細胞等の遺伝子改変は禁じられてい て, ヒトの生殖細胞または胚 (胚盤形成以前の胚細 胞) は, ES 細胞研究でもそうだが, 臨床研究に用い てはならない.これらの細胞にゲノムインテグレー 卜可能なべクターを導入し, 発生を継続した場合, 挿入されたべクターは成体となったヒトの生殖細胞 にも導入されているため, 次の世代にもべクター配 列は継承される可能性がある。生殖細胞系列のゲノ ムに挿入されたべクターが胚から個体への発生にど のような影響があるかは挿入部位が予測不可能であ ることもあって, 考えつかない疾患を呼び起こす可 
能性もある. 生殖細胞系列の遺伝子改変を許せば, 重篤な遺伝性疾患の治療目的などという曖昧な歯止 めは，突破される可能性がある。そうなれば，背の 高くなる遺伝子や頭のよくなる遺伝子改変など，い わゆるデザイナーズベイビーを生み出すことにもつ ながりかねない，遺伝子治療が行われる細胞を体細 胞に限定することは，現時点で必要な規制である。

\section{3）ゲノム編集技術を用いた engineered embryo}

ベクターを用いた遺伝子治療では遺伝子発現カ セットだけではなく、べクター配列なども，ゲノム 配列に挿入されてしまい，しかも，ヒトゲノム配列 のどこに配置されるかは運次第である。しかし，究 極の遺伝子治療は，例えば，遺伝子診断によって点 変異で早期終了コドンが出現するいわゆるナンセン 久変異の塩基置換をワイルドタイプの塩基に戻し, べ クター配列など余計な外来配列をゲノム配列に残さ ないことが理想である。ゲノム編集技術は，この理 想的な遺伝子治療を可能にする技術として注目され ている，ゲノム編集では，編集したい配列を正確に 認識して切る酵素が必要である。そのための人工制 限酵素として, 第一世代の zingfinger nuclease (ZFN), 第二世代の TALEN そして，第三世代 CRISPR-Cas が用いられている。とりわけ，CRISPR-Cas9 はコン ストラクト作製の容易さと, 切断効率の高さから, 2012 年に最初の報告が行われて以来, 急速に普及 している. CRISPR-Cas9 はユニーク配列を持つ一本 鎖ガイドRNA がターゲットに結合し，Caspase9 が DNA を切断する。 2 本鎖 DNA が切断される (double strand break: DSB) と，末端に相同性がない場合，数 塩基の欠失を生じて再結合するため, ガイド RNA をアミノ酸コード領域にデザインすれば，遺伝子は 破壊され，ノックアウトマウスの作製などに盛んに 利用されている．CRISPR-Cas9による切断と同時に ターゲット配列周辺に修復したい DNA 配列 (Homology directed repair(HDR) template)を細胞に導入する ことによって, 相同組み換えが生じ, 塩基置換や, 挿入久失を導入することもできる(図 $1 \mathbf{A})$ ）つまり， 上手くいけば，疾患の原因となっている配列の異常 をワイルドタイプへ修復することができる。それだ けではなく，2 種類のガイドRNA を用い，2つの 染色体領域をまたぐドナーテンプレート導入による 染色体転座修復の可能性まで提唱されている。しか
し，この技術もまだ完璧ではない。一つは，ガイド RNA に依存する切断配列特異性が完璧ではなく, ターゲット以外の類似した配列に DSB を起こすこ とがある(オフターゲット切断)。もう一つは, 修復 効率の問題で，受精卵への CRISPR-Cas9 導入による 単純なノックアウトマウス作製効率は約 $50 \%$ 以上 と高いが，ドナーテンプレートによる修復は $10 \%$ 程度と低い ${ }^{10)}$ 。さらに，マウス受精卵の状態に依存 するのではないかと考えられているが，ゲノム編集 できた細胞とそうでない細胞の入り交じったモザイ クマウスが生まれることがあることも問題である ${ }^{11}$

\section{(図 1B)}

このような未だ不完全な技術をヒトに応用しよう とする試みには，多くの人が早すぎると感じるだろ うし，日本の研究者なら，ヒトの生殖細胞等の遺伝 子改变禁止という条項が入った倫理指針に逆らって まで，この技術を用いたいとは思わないだろう。と ころが，2015 年春，中国のグループが， $\beta$ サラセミ アの受精卵を使って遺伝子改変の試みを行い，4月 18 日, Protein \& Cell という雑誌に論文が発表された。 3 前核受精卵という，卵子に2つの精子が受精し， 5 日程度で死んでしまう卵(絶対に発生しないので倫 理的問題を回避できていると主張したいのだろう) に, CRISPR-Cas9をマイクロインジェクションで導 入し，半分程度の卵で意図したとおりのゲノム編集 が行われていたことを明らかにした ${ }^{12)}$ 。しかし，マ ウスの実験などで予想されていたように，オフター ゲットのゲノム切断も生じていたことと, 狙ったと おりの修復ができた細胞とそうでない細胞が混在し たモザイク状態の胚も観察されたことを明らかにし た。この結果から，もっと技術を改良しないと臨床 には使えないという，至極当然の結論で結んでいた。 これに対し，Nature と Science 誌(両雑誌にこの論 文は投稿されていたが，倫理問題を理由に reject し ていた)は、コメントを発表し，それぞれ「ヒトの生 殖細胞ゲノムを編集すべきでない」13)，「ヒト胚を編

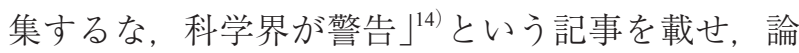
議を呼び起こしている。いずれも，未完成のこの技 術を用いて，ヒ卜生殖細胞系列のゲノムを改変する 研究は一時，ストップすべきで，まずは，科学者， 生命倫理学者, 法曹界, 一般市民などを巻き込んだ オープンな議論を基にルールを作ることが必要だと 
A

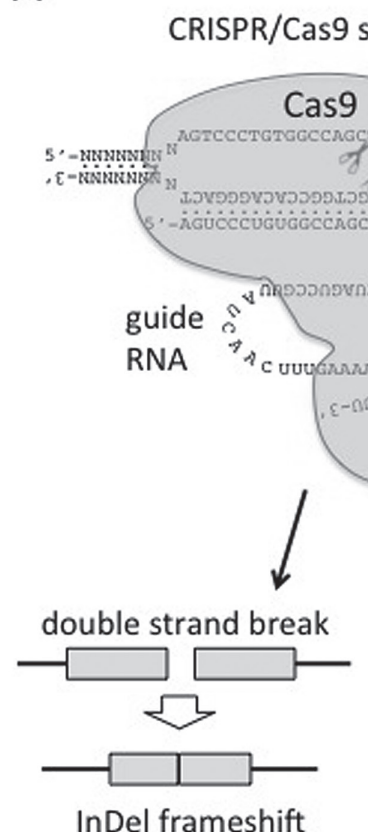

B

\section{マウス受精卵}

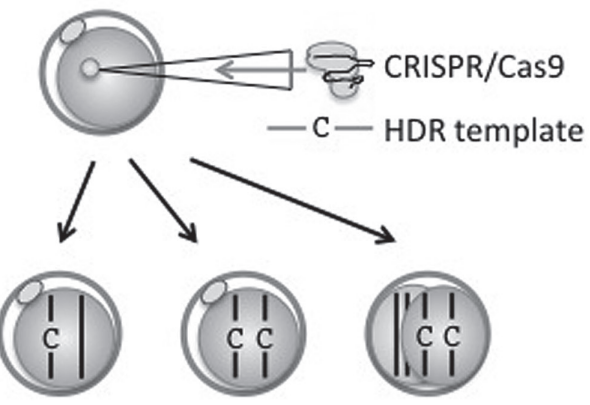

genome

DNA

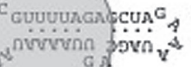

\author{
(1)
}

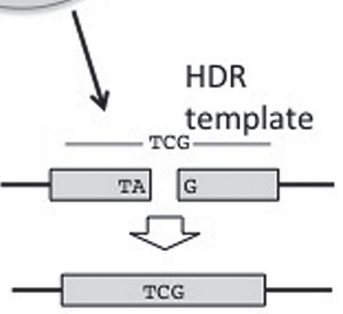

Homology directed repair

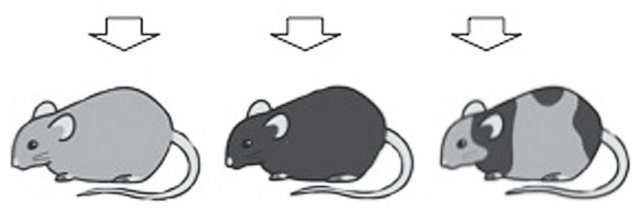

ヘテロマウス ワイルドタイプ モザイクマウス
マウス

図 1 CRISPR/Cas9 システム

(A)CRISPR/Cas9 の構造と遺伝子編集の仕組み. guide RNA 5’ 末 20 塩基がコーディング領域の相補的配列に結合すると, Cas9 が double strand break(DSB)を生じさせる。断端に Non-Homologous End JoiningによるDNA 修復が行われると，末端の 数塩基の欠失や挿入が起こりその数が 3 の倍数以外ならフレームシフト变異 (InDel frameshift) となり, 遺伝子機能は破壊さ れる。 また，DSB の時，相同配列内に修復したい配列を持つドナーテンプレート（HDR template）を入れておけば，望み通り の塩基置換を生じさせることができる. しかし，切断部位の特異性は 20 塩基で決定されているため, 類似した配列におけ るオフターゲット切断が生じる可能性がある。（B）マウス受精卵に，CRISPR/Cas9 と HDR templateを注入すると， 2 倍体の 片方のみが修復されればへテロマウス，両方が修復されればワイルドタイプ，そして受精卵が既に卵割を始めている場合な どでは，修復された細胞とそうでない細胞の混在したモザイクマウスが出来上がる。

訴えている，日本でも，ようやくゲノム編集に関す る話題がTVプログラムなどで紹介されるように なってきたが, ヒト胚のゲノム編集についても議論 が活発に行われることが望まれる。

\section{4）無視されている突然変異のリスク}

遺伝性疾患の遺伝子解析によって判明した“污れ た血”は，遺伝子編集で修復してしまえば安心だろ うか．また，遺伝病は本当に対岸の火事に過ぎない のだろうか. 遺伝学を理解していれば, これらは, 明らかに間違っていることがわかる 種類知られている常染色体劣性遺伝病の多くは, 4 10 万人に 1 人の割合 $\left(\mathrm{q}^{2}\right)$ で生まれるが，それぞ れの疾患の保因者頻度 $(2 \mathrm{pq})$ はおよそ 100 人に 1 人 と見積もられ，1/100に600〜700 種類をかけると， 全てのヒトは 6〜 7つの劣性遺伝病の保因者である. つまり，遺伝性疾患は対岸の火事では済まされない
し，ゲノム編集で修復しても別の“污れた血”が隠れ ていることに気づくべきである，また，突然変異も 避けることはできない. ヒトは平均的生存期間に $10^{17}$ 回ほどの細胞分裂を繰り返すと見込まれている ため， $6 \times 10^{26}$ 個の塩基が DNA に複製される。しか し, DNA ポリメラーゼの複製精度は $10^{-9 \sim-11} に 1$ 塩 基置換を生じる程度なので，一生の間に各遺伝子に はかなりの数の変異が生じていることになる，生殖 細胞も例外ではない, 殊に精原細胞はほぼ一生細胞 分裂を続けるので，出生までに全分裂を終える卵原 細胞に比べて変異率が高い. 実際, 突然変異による ある種の優性遺伝病の発生頻度は, 父親の年齢が上 がるほど上昇することが知られている。また，突然 変異率は，実際どの程度なのか， $\mathrm{X}$ 連鎖劣性遺伝疾 患をモデルにした場合，次のように推定することが できる。(A)を，ある人類集団におけるX 連鎖劣性 
遺伝病の保因者頻度，(I)を男児における発症頻度, $(\mu)$ を, 新たな変異の発生頻度, $(f)$ を, この疾患の 罹患者が父親となり得る頻度, とする。世代間で $I$

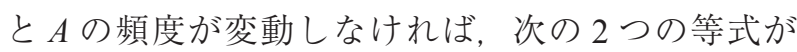
成立する。

$$
\begin{aligned}
& I=\mu+\frac{1}{2} A \\
& A=(I \times f)+2 \mu+\frac{1}{2} A
\end{aligned}
$$

（1）の式は，男性患児は，女性における新生突然 変異頻度と保因者から $1 / 2$ の確率で生まれる割合を 足した頻度で生まれてくることを示しており， の式は，女性保因者頻度は，男性患者が子供を作る 頻度と, 男女両方における新生突然变異による新た な保因者が生まれる頻度，そして女性保因者が $1 / 2$ の確率で保因者を産む頻度を足したものであること を示している. 例えば, Duchenne型筋ジストロフィー の場合，患者は子供を作ることができないので, $f=0$ である、したがって， $A=2 \mu+A / 2$ となるから $A=4 \mu$, $I=3 \mu$, つまり, Duchenne 型筋ジストロフィー患者 の 3 人に 1 人は新たな突然変異によって生まれてく ることを意味しており，臨床的観察に合致してい る. 血友病 A の場合, $f=0.7$ と仮定すると, $A=18 \mu$, $I=10 \mu$ となり，患者 10 に 1 人は突然変異による発生 たと推定される。これらのことから，遺伝性疾患は， 地球上の生物にとって宿命と言えるものであり，全 ての人の子孫に生ずる可能性はあることを理解して 倫理的課題を解いていく必要があると考える.

\section{4. おわりに}

遺伝子解析技術の発達に伴い, ヒトゲノムに潜む 様々なバリエーションが持つ意味が，広範に解き明 かされようとしている。それに伴って生じてきた 様々な課題と共に, 遺伝子治療, 殊にヒト胚におけ るゲノム編集について紹介し，その問題点について 私見を交えながら論じてみた。倫理に正解はなく， 社会・分化などと関わり合いながら醸成されるもの と思っている．読者の方々の議論の糧になれば幸い である。
著者の利益相反 $(\mathrm{COI})$ の開示 :

本論文発表内容に関連して開示すべき企業との利益 相反なし

\section{文献}

1）川島ひろ子：ヒトゲノム研究と社会(藤木典生, D. メイ サー，編），東京，ユウバイオス倫理研究会， 1992.

2）額賀淑郎, 津谷喜一郎：「遺伝子例外主義」問題の動向. 日医雑誌 134: 2385-2390, 2006.

3）林 弘正：非侵襲的出生前遺伝学的検査についての刑 事法的一考察。武蔵野大学政治経済研究所年報 8: 1$108,2014$.

4) Green RC, Berg JS, Grody WW, Kalia SS, Korf BR, Martin CL, McGuire AL, Nussbaum RL, O’Daniel JM, Ormond KE, Rehm HL, Watson MS, Williams MS, Biesecker LG; American College of Medical Genetics and Genomics: ACMG recommendations for reporting of incidental findings in clinical exome and genome sequencing. Genet Med 15: 565-574, 2013.

5) Anderson WF, Blaese RM, Culver K: The ADA human gene therapy clinical protocol: Points to Consider response with clinical protocol, July 6, 1990. Hum Gene Ther 1: 331-362, 1990.

6) Cavazzana-Calvo M, Hacein-Bey S, de Saint Basile G, Gross F, Yvon E, Nusbaum P, Selz F, Hue C, Certain S, Casanova JL, Bousso P, Deist FL, Fischer A: Gene therapy of human severe combined immunodeficiency (SCID)-X1 disease. Science 288: 669-672, 2000.

7) Marshall E: Clinical research. Gene therapy a suspect in leukemia-like disease. Science 298: 34-35, 2002.

8) Cartier N, Hacein-Bey-Abina S, Bartholomae CC, Veres G, Schmidt M, Kutschera I, Vidaud M, Abel U, Dal-Cortivo L, Caccavelli L, Mahlaoui N, Kiermer V, Mittelstaedt D, Bellesme C, Lahlou N, Lefrère F, Blanche S, Audit M, Payen E, Leboulch $\mathrm{P}$, l'Homme B, Bougnères $\mathrm{P}$, Von Kalle $\mathrm{C}$, Fischer A, Cavazzana-Calvo M, Aubourg P: Hematopoietic stem cell gene therapy with a lentiviral vector in X-linked adrenoleukodystrophy. Science 326: 818-823, 2009.

9) Nathwani AC, Tuddenham EG, Rangarajan S, Rosales C, McIntosh J, Linch DC, Chowdary P, Riddell A, Pie AJ, Harrington C, O’Beirne J, Smith K, Pasi J, Glader B, Rustagi P, Ng CY, Kay MA, Zhou J, Spence Y, Morton CL, Allay J, Coleman J, Sleep S, Cunningham JM, Srivastava D, BasnerTschakarjan E, Mingozzi F, High KA, Gray JT, Reiss UM, Nienhuis AW, Davidoff AM: Adenovirus-associated virus vector-mediated gene transfer in hemophilia B. N Engl J Med 365: 2357-2365, 2011.

10) Fujihara Y, Ikawa M: CRISPR/Cas9-based genome editing in mice by single plasmid injection. Meth Enzymol 546: 319 336, 2014.

11) Yen ST, Zhang M, Deng JM, Usman SJ, Smith CN, ParkerThornburg J, Swinton PG, Martin JF, Behringer RR: Somatic mosaicism and allele complexity induced by CRISPR/Cas9 RNA injections in mouse zygotes. Dev Biol 393: 3-9, 2014.

12) Liang $\mathrm{P}, \mathrm{Xu} \mathrm{Y}$, Zhang $\mathrm{X}$, Ding $\mathrm{C}$, Huang $\mathrm{R}$, Zhang $\mathrm{Z}$, Lv J, 
Xie X, Chen Y, Li Y, Sun Y, Bai Y, Songyang Z, Ma W, Zhou C, Huang J: CRISPR/Cas9-mediated gene editing in human tripronuclear zygotes. Protein Cell 6: 363-372, 2015.

13) Lanphier E, Urnov F, Haecker SE, Werner M, Smolenski J: Don't edit the human germ line. Nature 519: 410-411, 2015.
14) Kaiser J, Normile D: Bioethics. Embryo engineering study splits scientific community. Science 348: 486-487, 2015.

15) Nussbaum RL, McInnes RR, Willard HF: Genetics in Medicine. Philadelphia, Saunders Elsevier, 2007. 